\title{
ATTITUDE OF RURAL HOUSEHOLDS OF SOUTH WESTERN NIGERIA TOWARDS UTILIZATION OF WATER SANITATION FACILITIES
}

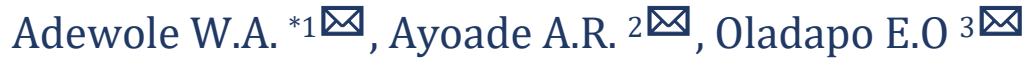 \\ ${ }^{* 1}$ Assistant Lecturer, Department of Agricultural Extension and Rural Development, Ladoke \\ Akintola University of Technology, Ogbomoso, Nigeria \\ 2 Professor of Rural Sociology, Department of Agricultural Extension and Rural Development, \\ Ladoke Akintola University of Technology, Ogbomoso, Nigeria \\ ${ }^{3}$ Doctoral Students Department of Agricultural Extension and Rural Development, Ladoke \\ Akintola University of Technology, Ogbomoso, Nigeria
}

DOI: https://doi.org/10.29121/granthaalayah.v9.i3.2021.3566

\section{Article Type: Research Article}

Article Citation: Adewole W.A., Ayoade A.R., and Oladapo E.O. (2021). ATTITUDE OF RURAL HOUSEHOLDS OF SOUTH WESTERN NIGERIA TOWARDS UTILIZATION OF WATER SANITATION

FACILITIES. International Journal of Research -GRANTHAALAYAH, 9(3), 291-300.

https://doi.org/10.29121/granthaa layah.v9.i3.2021.3566

Received Date: 17 February 2021

Accepted Date: 31 March 2021

\section{Keywords:}

Attitude

Households

Sanitation

Facilities

\section{ABSTRACT}

The study examined the Attitude of rural households of south west Nigeria towards utilization of water sanitation facilities the study specifically described the socio-economic characteristics of the rural household heads; identified various sources of water supply and their providers; determined the attitude of respondents to the utilization of water sanitation facilities and identified the constraints to water sanitation facilities utilization. The population of the study comprised of all the rural households in Ondo and Oyo States in Southwestern of Nigeria. The sampling procedure employed was multistage sampling technique to select 355 household heads comprising a total of 167 rural household considered out of 278 rural households from the selected cells in Oyo state while a total of 188 rural household heads selected out of 314 rural household heads from the selected cells in Ondo State for the study. The data for the study were analyzed with descriptive statistics such as frequency count, percentage, mean and standard deviation while inferential statistical tools such as logistic regression analysis model and Pearson Product Moment Correlation analysis.

The result revealed a mean age of the respondents from Ondo State was 47 years while that of respondents from Oyo State was 45 years. Rain water collection was the major source of improved water supply from Ondo State (87.4\%) and Oyo State (86.7\%). Majority had favourable attitude towards utilization of water sanitation facilities while the level of utilization of water sanitation facilities is still on moderate level. The result of the Regression analysis model indicated that years of schooling ( $\left.\mathrm{t}=-3.758^{* * *} ; \mathrm{p}=0.000\right)$ and households' size $\left(\mathrm{t}=-2.089^{* *} ; \mathrm{p}=0.037\right)$ were significantly related to utilization of water sanitation facilities. It was therefore concluded that the utilization of water sanitation facilities was influenced by income level, household size and people's attitude/disposition towards water sanitation facilities. Since income level is a strong determinant of utilization of water sanitation facilities, there is need to make credit available to the rural households in case of breakdown of the facilities to enable immediate repairs thereby enhancing their health and utilization level. 
Attitude of Rural Households of South Western Nigeria Towards Utilization of Water Sanitation Facilities

\section{INTRODUCTION}

Water constitutes over $70 \%$ of the human body and is considered as the most vital component of life after oxygen (Doe, 2007). Available trends show that water also covers about $70 \%$ of the earth's surface and that only $1 \%$ of it is available to human for drinking. A recent report revealed that about 783 million people worldwide lack access to safe water supply while 2.5 billion people have no access to adequate sanitation (UNESCO, 2013). Water is needed in all aspects of life. It is not only human being that require a basic supply of reasonably good quality water in order to survive; water is needed for the survival and productivity of every life endeavour and all ecosystems, (World Health Organization and United Nation Children Educational Fund (WHO and UNICEF, 2014). Humans depend on a wide range of ecosystem services for multiple biological, economic, social and cultural needs. Water is not only essential for basic drinking, cooking, hygiene and ecosystem functioning, but also for producing food, energy, and indeed all the material products needed for daily life (Jerven, 2014). It also plays a dominant role in the spiritual and aesthetic lives of billions of people globally.

The importance of water is not only related to drinking but also plays a crucial role in cooking, washing, bathing, and other domestic activities. However, about 6 to 8 million people die annually from consequences of disasters and water related illnesses, inadequate sanitation and poor hygiene information (Moe, 2006). Water is also the main driver of illnesses such as diarrhea and typhoid, cholera and dysentery (Bradley et al., 2007). Such water related illnesses are often the major cause of premature death in children. This implies that any process that compromises the supply and distribution of safe water threatens human health, survival, growth and development which in turn affect involvement in agricultural production and other livelihood activities of the people negatively.

The adequate supply of efficient infrastructural facilities is a major headache of governments globally due to the enormous financial and capital outlay needed in their planning and implementation. Population surge and unpredictable weather condition resulting in climate change issues also affect effective supply of services that mostly rely on nature such as water provision. For example, rainfall and drought, the availability of water bodies like rivers, lakes and dams adversely affect provision of water services.

The Institute of Medicine (IOM, 2009) revealed that, though poverty has been a major impediment to accessing safe drinking water and sanitation facilities in many parts of the sub-Sahara Africa, access to, availability, and utilization of safe water sanitation facilities is a prerequisite to sustainable growth and development of communities around the world. Hunter et al., (2010) established a strong correlation between safe water supply and livelihoods, whether for productive or domestic uses. Water supply and water facilities maintenance play a major role in laying the foundation for economic growth, by increasing the assurance of supply as well as by improving water quality and therefore human health (Phillips et al., 2006).

The general effects of safe WATSAN facilities supply cannot be overestimated. Infectious diarrhea and other serious waterborne illnesses are leading causes of general ill health and mortality, particularly, infant mortality and malnutrition. Their impacts extend beyond health to economic in the form of lost work days and school absenteeism especially among the girl children. Investment in this area is to killer diseases like diarrhoea just as what immunization is to measles- a life-saver. The situation has further worsened as a result of the over reliance on primary agriculture production, low technological advancement, hiking population growth, climatic change, a blurred democratic governance environment and more recently corruption. These factors, among others, have resulted in fruitless attempts to improve many sectors of the economy including WATSAN in order to reduce poverty especially in the southern part of Nigeria. Consequently, the issue is compounded because of low population growth in these areas coupled with rural housing pattern where housing units are dispersed and scattered. This makes provision of WATSAN facilities capital intensive looking at the facility cost and the population to a facility.

\section{RESULTS AND DISCUSSION}

\subsection{SOCIO-ECONOMIC CHARACTERISTICS OF RESPONDENTS}

The distribution of respondents by age revealed that $8.7 \%$ were less than or equal to $8.7 \%, 21.7 \%$ were between 31 and 40 years, 38\% were between 41 and 50\%, 20.6\% were between 51 and 60 years of age while 11\% were above 60 years of age. Majority (69\%) were male while 31\% were female. 10\% were single, majority (82\%) were married, $2.8 \%$ were divorced, $2.3 \%$ separated while another $2.8 \%$ were widowed. $60.3 \%$ were Christians, $39.7 \%$ 
were Muslims. According to level of education, $21.7 \%$ did not have formal education, 36.6\% completed Primary School, 31.3\% had Secondary education, 2.5\% attended College of Education and Polytechnic while 5.4\% attended University. $4.2 \%$ had 1 and 2 household size, $16.9 \%$ had 3 and 4, 54.4\% had between 5 and 6 while $24.5 \%$ had above 6 household size. A little below half (48.5\%) were Farmers, 31.8\% were traders, 8.5\% were Civil servants, 10.1\% were into Artisanship while $1.1 \%$ belong into category of unspecified others.

Table 1: Socio-economic Characteristics of Respondents

\begin{tabular}{|c|c|c|}
\hline Socio-economic & Frequency & Percentage \\
\hline Age (years) & & \\
$\leq 30$ & 31 & 8.7 \\
$31-40$ & 77 & 21.7 \\
$41-50$ & 135 & 38.0 \\
$51-60$ & 73 & 20.6 \\
Above 60 & 39 & 11.0 \\
Sex & & \\
Male & 245 & 69.0 \\
Female & 110 & 31.0 \\
Marital Status & & \\
Single & 36 & 10.0 \\
Married & 291 & 82.0 \\
Divorced & 10 & 2.8 \\
Separated & 8 & 2.3 \\
Widowed & 10 & 2.8 \\
Religion & & \\
Christianity & 214 & 60.3 \\
Islam & 141 & 39.7 \\
Traditional & 0 & 0.00 \\
School last attended & & \\
None & 77 & 21.7 \\
Primary School & 130 & 36.6 \\
Secondary School & 111 & 31.3 \\
College of Education & 9 & 2.5 \\
Polytechnic & 9 & 2.5 \\
University & 19 & 5.4 \\
Household size & & \\
1-2 & 15 & 4.2 \\
3-4 & 60 & 16.9 \\
5-6 & 193 & 54.4 \\
Above 6 & 87 & 24.5 \\
Primary Occupation & & \\
Farming & 172 & 48.5 \\
Trading & 113 & 31.8 \\
Civil service & 30 & 8.5 \\
Artisanship & 36 & 10.1 \\
Others & 4 & 1.1 \\
\hline
\end{tabular}

Source: Field Survey, 2020

\subsection{SOURCES OF WATER FACILITIES AND THEIR PROVIDERS}

Based on the result in the Table 2, the unimproved sources of water facilities identified from in the rank order include surface water (river, dam, lake, pond, stream, canal, irrigation channels) (75.4\%), unprotected dug well $(36.2 \%)$, bottled water $(13.8 \%)$, unprotected spring $(10.1 \%)$, vendor provided water $(5.3 \%)$ and tanker-truck 
provider (1.6\%). Moreover, Community Development Association (CDA) was the major provider of majority of unimproved water facilities in Oyo State which include surface water (river, dam, lake, pond, stream, canal, and irrigation channels) (57.4\%), unprotected dug well (13.3\%) and unprotected spring (10.1\%). Individual households (self) were the major providers of surface water (river, dam, lake, pond, stream, canal, irrigation channels) (15.4\%), bottled water (9.0\%), unprotected dug well (4.8\%) and vendor provided water (2.7\%). Furthermore, neighbour and friends (N/F) were major providers of unprotected dug well (18.1\%), vendor provided water (1.6\%), bottled water $(1.1 \%)$ and surface water (river, dam, lake, pond, stream, canal, and irrigation channels) (1.1\%). Moreover, Local Government Council (LGC) was one of the major providers of bottled water (2.1\%), tanker-truck provider (1.1\%) and surface water (river, dam, lake, pond, stream, canal, and irrigation channels) (1.1\%). Also, MWR was one of the providers of bottled water (1.1\%). Also, the finding indicates that surface water (river, dam, lake, pond, stream, canal, irrigation channels) was the major unimproved sources of water facilities among rural households in Oyo State. The finding from this study also indicates that many rural households depend on unimproved sources of water facilities through diverse avenues. This development often times expose them to numerous waters borne diseases with attending reduction in time devoted to their farming and other livelihood activities and eventual reduction in production and income from their livelihood activities. In line with this assumption, Onesmo and Holmes (2006) established that lack of potable water and basic sanitation services remains one of the world's most urgent health issues. Similarly, Hunter (2010) claimed that access to a safe water supply for drinking, cooking, and personal hygiene is an essential prerequisite for health.

Table 2: Distribution of respondents by sources of water facilities and their providers

\begin{tabular}{|c|c|c|c|c|c|c|c|c|c|c|}
\hline \multirow{2}{*}{$\begin{array}{c}\text { Water } \\
\text { Facilities } \\
\text { Improved } \\
\end{array}$} & \multicolumn{9}{|c|}{ Provider of Water Sanitation Facilities } & \multirow[b]{2}{*}{ None } \\
\hline & UNICEF & WHO & WATSAN & MWR & FBO & LGC & $\mathrm{N} / \mathrm{F}$ & CDA & SELF & \\
\hline $\begin{array}{c}\text { sources } \\
\text { Household }\end{array}$ & $2(1.1)$ & $0(0.0)$ & $3(1.6)$ & $14(7.4)$ & $3(1.6)$ & $10(5.3)$ & $8(4.3)$ & $3(1.6)$ & $5(2.7)$ & $\begin{array}{c}140 \\
(74.5) \\
\end{array}$ \\
\hline $\begin{array}{l}\text { connection } \\
\text { Public stand }\end{array}$ & $2(1.1)$ & $0(0.0)$ & $2(1.1)$ & $6(3.2)$ & $4(2.1)$ & $3(11.7)$ & $9(3.7)$ & $9(4.8)$ & $2(1.1)$ & $\begin{array}{c}120 \\
(63.8)\end{array}$ \\
\hline $\begin{array}{c}\text { pipes } \\
\text { Boreholes }\end{array}$ & $0(0.0)$ & $0(0.0)$ & $0(0.0)$ & $1(0.5)$ & $5(2.7)$ & $74(39.4)$ & $32(17.0)$ & $2(1.1)$ & $10(5.3)$ & $\begin{array}{c}64 \\
(34.0) \\
\end{array}$ \\
\hline $\begin{array}{c}\text { Protected } \\
\text { dug }\end{array}$ & $0(0.0)$ & $0(0.0)$ & $0(0.0)$ & $3(1.6)$ & $3(1.6)$ & $11(5.9)$ & $80(42.6)$ & $26(13.8)$ & $28(14.9)$ & $\begin{array}{c}37 \\
(19.7)\end{array}$ \\
\hline $\begin{array}{c}\text { well } \\
\text { Protected }\end{array}$ & $4(2.1)$ & $0(0.0)$ & $0(0.0)$ & $0(0.0)$ & $0(0.0)$ & $4(2.1)$ & $2(1.1)$ & $5(2.7)$ & $10(5.3)$ & $\begin{array}{c}163 \\
(86.7) \\
\end{array}$ \\
\hline $\begin{array}{c}\text { springs } \\
\text { Rain water } \\
\text { collection }\end{array}$ & $2(1.1)$ & $0(0.0)$ & $0(0.0)$ & $0(0.0)$ & $0(0.0)$ & $0(0.0)$ & $9(4.8)$ & $8(4.3)$ & $144(76.6)$ & $\begin{array}{c}25 \\
(13.3)\end{array}$ \\
\hline \multicolumn{11}{|l|}{$\begin{array}{l}\text { Unimproved } \\
\text { Sources }\end{array}$} \\
\hline $\begin{array}{l}\text { Unprotected } \\
\text { dug well }\end{array}$ & $0(0.0)$ & $0(0.0)$ & $0(0.0)$ & $0(0.0)$ & $0(0.0)$ & $0(0.0)$ & $34(18.1)$ & $25(13.3)$ & $9(4.8)$ & $\begin{array}{c}120 \\
(63.8)\end{array}$ \\
\hline $\begin{array}{c}\text { Unprotected } \\
\text { spring }\end{array}$ & $0(0.0)$ & $0(0.0)$ & $0(0.0)$ & $0(0.0)$ & $0(0.0)$ & $0(0.0)$ & $0(0.0)$ & $19(10.1)$ & $0(0.0)$ & $\begin{array}{c}169 \\
(89.9) \\
\end{array}$ \\
\hline $\begin{array}{l}\text { Vendor - } \\
\text { provided } \\
\text { water }\end{array}$ & $0(0.0)$ & $0(0.0)$ & $0(0.0)$ & $0(0.0)$ & $0(0.0)$ & $0(0.0)$ & $3(1.6)$ & $2(1.1)$ & $5(2.7)$ & $\begin{array}{c}178 \\
(94.7)\end{array}$ \\
\hline $\begin{array}{c}\text { Bottled } \\
\text { water }\end{array}$ & $0(0.0)$ & $0(0.0)$ & $0(0.0)$ & $2(1.1)$ & $0(0.0)$ & $4(2.1)$ & $2(1.1)$ & $1(0.5)$ & $17(9.0)$ & $\begin{array}{c}162 \\
(86.2)\end{array}$ \\
\hline $\begin{array}{l}\text { Tanker- } \\
\text { truck } \\
\text { provider }\end{array}$ & $0(0.0)$ & $0(0.0)$ & $0(0.0)$ & $0(0.0)$ & $0(0.0)$ & $2(1.1)$ & $1(0.5)$ & $0(0.0)$ & $0(0.0)$ & $\begin{array}{c}185 \\
(98.4)\end{array}$ \\
\hline $\begin{array}{c}\text { Surface } \\
\text { water }\end{array}$ & $1(0.5)$ & $0(0.0)$ & $0(0.0)$ & $0(0.0)$ & $0(0.0)$ & $2(1.1)$ & $2(1.1)$ & $108(57.4)$ & $29(15.4)$ & $\begin{array}{c}46 \\
(24.5) \\
\end{array}$ \\
\hline
\end{tabular}




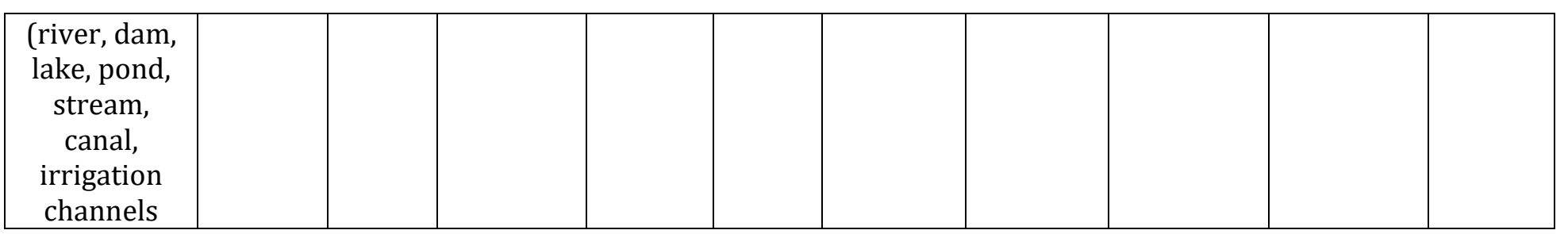

KEYS: UNICEF: United Nation Children Education Fund, WHO: World Health Organization, WATSAN: Water and Sanitation Agency, WMR: Ministry of Water Resources, FBO: Faith Based Organizations, N/F: Neighbors and Friends,

LGC: Local Government Council, CDA: Community Development Association.

WMS $=$ Weighted Mean Score

*Multiple Response

Source: Field Survey, 2020

\subsection{ATTITUDE OF RESPONDENTS TOWARDS WATER FACILITIES UTILIZATION}

The results (Table 3), respondents' attitude to the utilization of water sanitation facilities in the rank order include the fact Contaminated water poses health risks that can be reduced by improved storage conditions and household treatment and The use of good water treatment prevents microbial contamination (WMS=3.88), Water must be stored in neat and closed containers to prevent germs (WMS=3.84), Getting water from improved sources will deliver me and my household from waterborne diseases (WMS=3.83), Latrine must be sited far away from water sources or facilities to prevent contamination (WMS=3.78), Treated community water supplies generally re of high microbiological quality and therefore safe with respect to waterborne microbial disease risks (WMS=3.75), Safe disposal of refuse and the use of clean and covered containers are necessary to prevent germs and diseases (WMS=3.74), Regular utilization of water from borehole will prevent infection like cholera and dysentery (WMS=3.68), Water from the borehole is preferable because it can be used directly without waiting for it to settle or looking for additional treatments (WMS=3.66) while Water of good quality has no taste (WMS=3.05), Frequent breakdown of the facilities without immediate repairs has made us loss interest (WMS=2.95), The facilities are difficult to operate and maintain (WMS=2.77), Lack of training on the operation of water pumps does not make us to use it (WMS=2.59), The facility is a bait by political class to get us to pledge our alliance or loyalty to them (WMS=2.27), Treated water may contain some sediments or residues that may be dangerous or injurious to health (WMS $=2.26$ ), The providers of the facilities are exploitative and have hidden agenda(WMS=1.88), The distance to the facility from my house is too long, so it is a waste of time and energy (WMS=1.85).

Table 3: Distribution of respondents by their attitudinal Statements in pooled data

\begin{tabular}{|c|c|c|c|c|c|c|c|}
\hline Attitudinal Statements & $\begin{array}{c}\text { Strongly } \\
\text { Agreed }\end{array}$ & Agreed & Undecided & Disagree & $\begin{array}{c}\text { Strong } \\
\text { Disagree }\end{array}$ & WMS & Rank \\
\hline $\begin{array}{c}\text { Getting water from improved } \\
\text { sources will deliver me and my } \\
\text { household from waterborne } \\
\text { diseases }\end{array}$ & $0(0.0)$ & $295(83.1)$ & $60(16.9)$ & $0(0.0)$ & $0(0.0)$ & 3.83 & $4^{\text {th }}$ \\
\hline $\begin{array}{c}\text { Treated community water supplies } \\
\text { generally re of high microbiological } \\
\text { quality and therefore safe with } \\
\text { respect to waterborne microbial } \\
\text { disease risks. }\end{array}$ & $0(0.0)$ & $271(76.3)$ & $81(22.8)$ & $0(0.0)$ & $3(0.8)$ & 3.75 & $6^{\text {th }}$ \\
\hline $\begin{array}{c}\text { Contaminated water poses health } \\
\text { risks that can be reduced by } \\
\text { improved storage conditions and } \\
\text { household treatment }\end{array}$ & $0(0.0)$ & $312(87.9)$ & $43(12.1)$ & $0(0.0)$ & $0(0.0)$ & 3.88 & $1^{\text {st }}$ \\
\hline $\begin{array}{c}\text { Water related diseases can be } \\
\text { avoided by regular use of water } \\
\text { facilities }\end{array}$ & $0(0.0)$ & $250(70.4)$ & $98(27.6)$ & $7(2.0)$ & $0(0.0)$ & 3.68 & $8^{\text {th }}$ \\
\hline
\end{tabular}


Attitude of Rural Households of South Western Nigeria Towards Utilization of Water Sanitation Facilities

\begin{tabular}{|c|c|c|c|c|c|c|c|}
\hline $\begin{array}{l}\text { The use of good water treatment } \\
\text { prevents microbial contamination }\end{array}$ & $0(0.0)$ & $316(89.0)$ & $36(10.1)$ & $3(0.8)$ & $0(0.0)$ & 3.88 & $1^{\text {st }}$ \\
\hline $\begin{array}{l}\text { Water from the borehole is } \\
\text { preferable because it can be used } \\
\text { directly without waiting for it to } \\
\text { settle or looking for additional } \\
\text { treatments }\end{array}$ & $0(0.0)$ & $241(67.9)$ & $109(30.7)$ & $5(1.4)$ & $0(0.0)$ & 3.66 & $10^{\text {th }}$ \\
\hline $\begin{array}{l}\text { Water must be stored in neat and } \\
\text { closed containers to prevent germs }\end{array}$ & $0(0.0)$ & $300(84.5)$ & $52(14.6)$ & $3(0.8)$ & $0(0.0)$ & 3.84 & $3^{\text {rd }}$ \\
\hline $\begin{array}{l}\text { Latrine must be sited far away from } \\
\text { water sources or facilities to } \\
\text { prevent contamination }\end{array}$ & $0(0.0)$ & $278(78.3)$ & $75(21.1)$ & $2(0.6)$ & $0(0.0)$ & 3.78 & $5^{\text {th }}$ \\
\hline $\begin{array}{l}\text { Regular utilization of water from } \\
\text { borehole will prevent infection like } \\
\text { cholera and dysentery }\end{array}$ & $0(0.0)$ & $763(74.1)$ & $77(21.7)$ & $9(2.5)$ & $6(1.7)$ & 3.68 & $8^{\text {th }}$ \\
\hline $\begin{array}{c}\text { Safe disposal of refuse and the use } \\
\text { of clean and covered containers are } \\
\text { necessary to prevent germs and } \\
\text { diseases }\end{array}$ & $0(0.0)$ & $288(81.1)$ & $58(16.3)$ & $0(0.0)$ & $6(1.7)$ & 3.74 & $7^{\text {th }}$ \\
\hline Water of good quality has no taste & $0(0.0)$ & $184(51.8)$ & $83(23.9)$ & $15(4.2)$ & $61(17.2)$ & 3.05 & $11^{\text {th }}$ \\
\hline $\begin{array}{l}\text { Lack of training on the operation of } \\
\text { water pumps does not make us to } \\
\text { use it. }\end{array}$ & $0(0.0)$ & $86(24.2)$ & $124(34.9)$ & $73(20.6)$ & $58(16.3)$ & 2.59 & $15^{\text {th }}$ \\
\hline $\begin{array}{l}\text { The distance to the facility from my } \\
\text { house is too long, so it is a waste of } \\
\text { time and energy }\end{array}$ & $0(0.0)$ & $48(11.8)$ & $68(19.2)$ & $55(15.5)$ & $176(49.6)$ & 1.85 & $19^{\text {th }}$ \\
\hline $\begin{array}{l}\text { Treated water may contain some } \\
\text { sediments or residues that may be } \\
\text { dangerous or injurious to health }\end{array}$ & $0(0.0)$ & $42(11.8)$ & $127(35.8)$ & $82(23.1)$ & $88(24.8)$ & 2.26 & $17^{\text {th }}$ \\
\hline $\begin{array}{c}\text { The providers of the facilities are } \\
\text { exploitative and have hidden } \\
\text { agenda }\end{array}$ & $0(0.0)$ & $15(4.2)$ & $110(31.0)$ & $82(23.1)$ & 113(31.8) & 1.88 & $18^{\text {th }}$ \\
\hline $\begin{array}{l}\text { The community members were not } \\
\text { carried along before the } \\
\text { construction of the facilities, so I } \\
\text { don't use it. }\end{array}$ & $0(0.0)$ & $9(2.5)$ & $19(5.4)$ & $56(15.8)$ & $251(70.7)$ & 1.28 & $20^{\text {th }}$ \\
\hline $\begin{array}{c}\text { The facility is a bait by political class } \\
\text { to get us to pledge our alliance or } \\
\text { loyalty to them }\end{array}$ & $0(0.0)$ & $25(7.0)$ & $160(45.1)$ & $90(25.4)$ & $45(12.7)$ & 2.27 & $16^{\text {th }}$ \\
\hline $\begin{array}{l}\text { Good quality water can also get } \\
\text { contaminated in the home due to } \\
\text { inadequate and unsanitary storage } \\
\text { conditions that allow for the } \\
\text { introduction and/or proliferation of } \\
\text { disease-causing microbes. }\end{array}$ & $0(0.0)$ & 211(59.4) & $57(16.1)$ & $7(2.0)$ & $55(15.5)$ & 3.05 & $11^{\text {th }}$ \\
\hline $\begin{array}{l}\text { The facilities are difficult to operate } \\
\text { and maintain }\end{array}$ & $0(0.0)$ & $164(46.2)$ & $79(22.3)$ & $17(4.8)$ & $55(15.5)$ & 2.77 & $14^{\text {th }}$ \\
\hline $\begin{array}{c}\text { Frequent breakdown of the facilities } \\
\text { without immediate repairs has } \\
\text { made us loss interest }\end{array}$ & $0(0.0)$ & $207(58.3)$ & $52(14.6)$ & $0(0.0)$ & $63(17.7)$ & 2.95 & $13^{\text {th }}$ \\
\hline
\end{tabular}

WMS = Weighted Mean Score

Source: Field Survey, 2020 


\subsection{CONSTRAINTS TO UTILIZATION OF WATER SANITATION FACILITIES}

Table 4. showed the distribution of respondents by pooled, the constraints to water and sanitation facilities utilization in their rank order include Financial constraint in case of breakdown of the facilities (WMS $=2.90)$, Poor maintenance culture (WMS $=2.90$ ), Unwillingness of the users to cooperate (WMS $=2.82$ ), Ineffective promotion of public support (WMS $=2.66$ ), Inadequate training on the operation and maintenance (WMS $=2.45$ ), Poor support from the donors in terms of maintenance and operation (WMS $=2.43$ Wrong site selection (2.25) Long distance to water source (WMS =1.61). Others include complexity of operation (WMS =1.35) 4and Non-compatibility with the culture and religion (WMS = 1.31).

Table 4: Distribution of respondents by constraints to the utilization of water and sanitation facilities in pooled

\begin{tabular}{|c|c|c|c|c|c|c|}
\hline $\begin{array}{c}\text { Constraints to the utilization of water } \\
\text { sanitation facilities }\end{array}$ & $\begin{array}{c}\text { Very } \\
\text { serious }\end{array}$ & Serious & $\begin{array}{c}\text { Fairly } \\
\text { serious }\end{array}$ & $\begin{array}{c}\text { Not } \\
\text { serious }\end{array}$ & WMS & Rank \\
\hline $\begin{array}{c}\text { Long distance to water source } \\
\begin{array}{c}\text { Poor support from the donors in terms of } \\
\text { maintenance and operation }\end{array}\end{array}$ & $209(58.9)$ & $72(20.3)$ & $114(32.1)$ & $64(18.0)$ & 1.61 & $8^{\text {th }}$ \\
\hline $\begin{array}{c}\text { Non-compatibility with the culture and } \\
\text { religion }\end{array}$ & $54(15.2)$ & $38(10.7)$ & $226(63.7)$ & $37(10.4)$ & 1.31 & $10^{\text {th }}$ \\
\hline $\begin{array}{c}\text { Complexity of operation } \\
\text { Inadequate training on the operation and } \\
\text { maintenance }\end{array}$ & $211(59.4)$ & $99(27.9)$ & $37(10.4)$ & $8(2.3)$ & 2.45 & $5^{\text {th }}$ \\
\hline $\begin{array}{c}\text { Financial constraint in case of breakdown of } \\
\text { the facilities }\end{array}$ & $325(91.5)$ & $26(7.3)$ & $4(1.1)$ & $0(0.0)$ & 2.90 & $1^{\text {st }}$ \\
\hline Ineffective promotion of public support & $263(74.1)$ & $66(18.6)$ & $26(7.3)$ & $4(1.1)$ & 2.66 & $4^{\text {th }}$ \\
\hline Poor maintenance culture & $32(90.4)$ & $32(9.0)$ & $2(0.6)$ & $0(0.0)$ & 2.90 & $1^{\text {st }}$ \\
\hline Wrong site selection & $137(38.6)$ & $171(48.2)$ & $47(13.2)$ & $0(0.0)$ & 2.25 & $7^{\text {th }}$ \\
\hline
\end{tabular}

WMS = Weighted Mean Score

Source: Field Survey, 2020

\subsection{LEVEL OF UTILIZATION OF WATER SANITATION FACILITIES}

The utilization of Clean and covered containers was ranked highest among utilized water sanitation facilities with a weighted mean score (WMS) of 2.92. Others in their rank order include use of Soapy water (WMS $=2.91$ ), hand washing (WMS $=2.90$ ), boiling (WMS $=2.86$ ), protected well (WMS $=2.78$ ), improved sewage containers (WMS $=2.73$ ), hand pump (WMS $=2.60$ ), point of use water treatment with additives (WMS $=2.56)$, borehole $(\mathrm{WMS}=2.45)$, public stand pipes (WMS $=1.03$ ), solar disinfectant $(\mathrm{WMS}=0.90)$, filter technology $(\mathrm{WMS}=0.85)$, hand sanitizers $(\mathrm{WMS}=0.75)$ and Ultraviolet filtration device (WMS $=0.62$ ). The use of clean and covered container was the major method used by the respondents in the southwestern Nigeria.

Table 5: Distribution of respondents by utilization of Water Sanitation Facilities in pooled data

\begin{tabular}{|c|c|c|c|c|c|c|}
\hline Water Sanitation Facilities & Always & Sometimes & Rarely & Never & WMS & Rank \\
\hline Household Water Treatment Storage & & & & & & \\
\hline Filter technology & $49(13.8)$ & $55(15.5)$ & $45(12.7)$ & $206(58.0)$ & 0.85 & $12^{\text {th }}$ \\
\hline Point of use water treatment with additives & $246(69.3)$ & $77(21.7)$ & $20(5.6)$ & $12(3.4)$ & 2.57 & $8^{\text {th }}$ \\
\hline Ultraviolet filtration device & $29(8.2)$ & $47(13.2)$ & $38(10.7)$ & $241(67.9)$ & 0.62 & 14 th \\
\hline Solar disinfectant & $76(21.4)$ & $33(9.3)$ & $25(7.0)$ & $221(62.3)$ & 0.90 & $11^{\text {th }}$ \\
\hline Boiling & $320(90.1)$ & $24(6.8)$ & $8(2.3)$ & $3(0.8)$ & 2.86 & $4^{\text {th }}$ \\
\hline Clean and covered containers & $327(92.1)$ & $28(7.9)$ & $0(0.0)$ & $0(0.0)$ & 2.92 & $1^{\text {st }}$ \\
\hline Improved sewage containers & $276(77.7)$ & $61(17.2)$ & $18(5.1)$ & $0(0.0)$ & 2.73 & $6^{\text {th }}$ \\
\hline Hand washing hardware & & & & & & \\
\hline
\end{tabular}


Attitude of Rural Households of South Western Nigeria Towards Utilization of Water Sanitation Facilities

\begin{tabular}{|c|c|c|c|c|c|c|}
\hline Hand washing & $327(92.1)$ & $24(6.8)$ & $1(0.3)$ & $3(0.8)$ & 2.90 & $3^{\text {rd }}$ \\
\hline Soapy water & $330(93.0)$ & $21(5.9)$ & $1(0.3)$ & $3(0.8)$ & 2.91 & $2^{\text {nd }}$ \\
\hline Hand sanitizers & $18(5.1)$ & $41(11.5)$ & $131(36.9)$ & $165(46.5)$ & 0.75 & $13^{\text {th }}$ \\
\hline Water supply technologies & & & & & & \\
\hline Hand pump & $277(78.0)$ & $25(7.0)$ & $43(12.1)$ & $10(2.8)$ & 2.60 & $7^{\text {th }}$ \\
\hline Borehole & $243(68.5)$ & $42(11.8)$ & $56(16.8)$ & $14(3.9)$ & 2.45 & $9^{\text {th }}$ \\
\hline Protected well & $290(81.7)$ & $55(15.5)$ & $7(2.0)$ & $3(0.8)$ & 2.78 & $5^{\text {th }}$ \\
\hline Public stand pipes & $39(11.0)$ & $42(11.8)$ & $163(45.9)$ & $111(31.3)$ & 1.03 & $10^{\text {th }}$ \\
\hline
\end{tabular}

WMS = Weighted Mean Score

Source: Field Survey, 2020

\section{Hypotheses Testing}

\subsection{CORRELATION BETWEEN KNOWLEDGE OF WATER SANITATION FACILITIES AND LEVEL OF UTILIZATION OF WATER SANITATION FACILITIES}

\section{$\mathrm{HO}_{1}$ : There is no significant relationship between knowledge of water source contamination and level of utilization of water sanitation information}

The result of the Pearson's Products Moment Correlation (PPMC) analysis in Table 6 indicated that the joint effect of the combination of all the knowledge of water source contamination (INDEXK) $(r=0.064 ; p=0.227)$ was positive but not significantly related to level of utilization of water sanitation facilities. However, individual variable (water source contamination) such as locating latrine close to the water source ( $\mathrm{r}=0.196^{* * *} ; \mathrm{p}=0.000$ ), water not flowing/stagnant water body/pond $\left(\mathrm{r}=0.093^{*} ; \mathrm{p}=0.081\right)$, disposing trash near the water source $\left(\mathrm{r}=-0.090^{*}\right.$; $\mathrm{p}=0.092)$, not properly plugging in the holes of the water pipe $\left(\mathrm{r}=0.210^{* * *} ; \mathrm{p}=0.000\right)$, well not having walling $\left(\mathrm{r}=0.113^{* *} ; \mathrm{p}=0.034\right)$, no cover/lid to protect the well $\left(\mathrm{r}=0.100^{*} ; \mathrm{p}=0.060\right)$, collection of acidic rain $\left(\mathrm{r}=-0.163^{* * *}\right.$; $\mathrm{p}=0.002)$ and poor storage practices $\left(\mathrm{r}=-0.180^{* * *} ; \mathrm{p}=0.001\right)$ was significantly related to level of utilization of water sanitation facilities at different significant levels.

For instance, locating latrine close to the water source (1\%), water not flowing/stagnant water body/pond (1\%), not properly plugging in the holes of the water pipe (1\%) and well not having walling (5\%) were positively related to level of utilization of water sanitation facilities. However, disposing trash near the water source (1\%), collection of acidic rain (1\%) and poor storage practices (1\%) were inversely related to level of utilization of water sanitation facilities. Positive and significant relationship implying that the probability of utilization of water sanitation facilities increases with increasing knowledge of water source contamination among rural households. The inverse and significant relationship implying that the probability of utilization of water sanitation facilities decreases with decreasing knowledge of water source contamination among rural households. On the overall, the odd of the joint effect of the combination of all the knowledge of water source contamination favours increase in the utilization of water sanitation facilities as more rural households as their knowledge of water source contamination increases.

Table 6: Summary of correlation between the knowledge of water source contamination and level of utilization of water sanitation facilities

\begin{tabular}{|c|c|c|c|}
\hline Variable & R-Value & P-Value & Remarks \\
\hline Bathing/washing clothes at water source & 0.051 & 0.337 & NS \\
\hline Urinate/Defecate at the water source & 0.058 & 0.280 & NS \\
\hline Latrine close to the water source & $0.196^{* * *}$ & 0.000 & $\mathrm{~S}$ \\
\hline Water that does not flow/stagnant water body/pond & $0.093^{*}$ & 0.081 & $\mathrm{~S}$ \\
\hline Dispose trash near the water source & $-0.090^{*}$ & 0.092 & $S$ \\
\hline Trash fallen into the water source & -0.011 & 0.841 & NS \\
\hline Washing raw meat and raw fish near the water source & 0.066 & 0.213 & NS \\
\hline Indiscriminate use of fetcher & 0.025 & 0.635 & NS \\
\hline Not properly plugging in the holes of the water pipe & $0.210^{* * *}$ & 0.000 & $\mathrm{~S}$ \\
\hline Do not have separate bucket or rope at the well/using dirty bucket & -0.070 & 0.191 & NS \\
\hline
\end{tabular}




\begin{tabular}{|c|c|c|c|}
\hline Then well has no walling & $0.113^{* *}$ & 0.034 & $\mathrm{~S}$ \\
\hline $\begin{array}{l}\text { The animals can go into the water source/No fence/broken fence } \\
\text { around the pond }\end{array}$ & -0.056 & 0.292 & NS \\
\hline No cover/lid to protect the well & $0.100^{*}$ & 0.060 & $S$ \\
\hline Collection of acidic rain & $-0.163^{* * *}$ & 0.002 & $\mathrm{~S}$ \\
\hline Poor storage practices & $-0.180 * * *$ & 0.001 & $\mathrm{~S}$ \\
\hline INDEXK & 0.064 & 0.227 & NS \\
\hline
\end{tabular}

NS=Not Significant

S=Significant

**=Significant at $5 \%$ level

**=Significant at $5 \%$ level

Source: Data Analysis, 2020

\section{CONCLUSION AND RECOMMENDATION}

The study concluded that the utilization of water sanitation facilities was influenced by income level, household size and people's attitude/disposition towards water sanitation facilities. Since income level is a strong determinant of utilization of water sanitation facilities, there is need to make credit available to the rural households in case of breakdown of the facilities to enable immediate repairs thereby enhancing their health and utilization level.

\section{SOURCES OF FUNDING}

This research received no specific grant from any funding agency in the public, commercial, or not-for-profit sectors.

\section{CONFLICT OF INTEREST}

The author have declared that no competing interests exist.

\section{ACKNOWLEDGMENT}

None.

\section{REFERENCES}

[1] Doe, N. (2007). Problems of ground water contamination with focus on water borne diseases, causes and prevention. Applied Science Report. 5 (1), 34-41.

[2] Hunter PR, MacDonald AM, Carter RC (2010) Water Supply and Health. PLoS Med 7(11): e1000361. doi: 10.1371/journal.pmed.1000361International Assessment United Nations. Development Programme. New York.

[3] Jerven, M (2014). Benefits and Costs of the Data for Development Targets for the Post-2015 Development Agenda: Post-2015 Consensus. Copenhagen Consensus Center Working Paper. http://www.copenhagenconsensus.com//publication/post-2015-consensus-data-developmentassessment-jerven

[4] Moe, C. L., and Rheingans, R. D. (2006) Global challenges in water, sanitation and health. Journal of water and health, 4(S1), pp.41-57. Monitoring Programme on Water Supply and Sanitation. WHO/UNICEF

[5] Phillips, D., Daoudy, M., McCaffrey, S., Ojendal, J. and Turton, A. (2006) Trans- boundary Water Cooperation as a tool for water sanitation information prevention and for a broader benefit-sharing. Windhoek, Namibia: Phillips Robinson and Associates.

[6] UNESCO, (2013). State of the World population: Unleashing the potential of urban growth. 220 East 42nd Street, 23rd FL New York, NY 10017 ᄀ. S.A.www.unfpa.org 
Attitude of Rural Households of South Western Nigeria Towards Utilization of Water Sanitation Facilities

[7] UNICEF (2014), 'Drinking Water, Sanitation and Hygiene in Schools: Global Baseline Report', New York, United Nations Children's Fund and World Health Organization. 